\title{
A Study on Mobile Library Services through Wechat Public Platforms in
} the University

\author{
Fang $\mathrm{Tu}^{1}$ \\ ${ }^{1}$ Wuchang Institutes of Technology, Wuhan City, Hubei Province, 430065, China
}

Keywords: Wechat public platform; libraries; universities; mobile services

\begin{abstract}
With the continuous development of science and technology, new media have appeared. There are no limits to time and space for people's information acquisition through new media. This provides a lot of convenience. The most representative media is Wechat, a chatting application developed by Tencent. Related research workers connect the university libraries and Wechat together and extend functions of the university library, which lays a good foundation for mobile services. Teachers and students can search literature and documents in the university library through Wechat. It is very convenient for them to get information resources and has a positive influence on promoting the development of the university library construction. This article has a deep study on mobile library services in universities through Wechat and makes some implications to the relevant personnel, so that university libraries in our country can achieve a new level.
\end{abstract}

\section{Introduction}

At present, mobile Internet technology has made considerable achievements in development and popularizing rate of smart phones is also rising, which lay a good foundation for the construction of library mobile services in universities and bring great opportunities for the development of the library construction in universities. College students can read holdings in libraries through Wechat without limitations of time and space, which will meet their actual needs of readers' information acquisition. It has practical significance to deeply study mobile library services in universities through Wechat public platforms. The following is relevant content in detail.

\section{The General Situation of Mobile Library Services through Wechat Public Platforms}

The general situation of Wechat official accounts of libraries. The author searches Wechat with library as the keyword and finds more than a hundred results. There are more than fifty provincial official accounts, such as Guangzhou Library and Shanghai Library, which accounts for 40 percent of the total number. There are forty university official accounts with about 30 percent proportion of the total number, including Peking University Library, Tsinghua University Library. There are also many commercial libraries. More than half of Wechat official accounts have been officially certified. University libraries construct mobile services with Wechat as the platform and have gained official certification mark, so that these official accounts can obtain teachers and students' trust. It is convenient for teachers and students to get information and meets their diverse reading needs. Therefore, it is an important path to develop modernization of university libraries in China.

The development tendency of Wechat official accounts of university libraries. Wechat is new media and highly favored by many people after its initial release. With the development of Wechat, Tencent launched Wechat public platform in August 2012 and it develops very rapidly. Now, there exist over a million of Wechat public platforms. After an actual survey, the author finds the library has a long response time to information technology and it takes a long time to adapt to the modern information environment. However, the good news is that there are many library Wechat official accounts. Wechat versions are upgrading continuously, research efforts for the library management in universities have also been strengthened and the connotation of Wechat official accounts of university libraries has gradually improved. It is supposed that there will be 
more university libraries to construct Wechat official accounts and extend library services. This will promote the construction and development of university libraries ${ }^{[1]}$.

\section{The Advantages that University Libraries Make Use of Wechat Public Platforms to Develop Mobile Service}

Service cost is low. The reason why Wechat can be accepted in a short time by many people and the number of users continues to increase is that Wechat has a low use cost. Registration and information release on WeChat are free of charge, which lay a good foundation for information distribution and resource delivery of university libraries. This reduces capital investment on publicity of university libraries. Furthermore, we need to pay attention to that an officially certified account in an open environment is a multiple-function service platform. It provides a more favorable technical support. Compared to the development of APP and other software, using Wechat public platforms to construct mobile library services is more favorable, which can effectively reduce the funding to run mobile services in university libraries.

Information distribution is precise. The basic function of Wechat official accounts is to distribute information. Therefore, university libraries can use Wechat official accounts to publish the latest announcements, notices, recommended literature and other information, which provides more convenience for readers in university libraries. University libraries can adjust and arrange activities according to the received information to ensure that libraries can participate in reading activities and collect or search reading materials. The university library, as an information distribution platform, should publish collected and edited information irregularly on the Wechat official accounts. Readers can effectively receive information tips. To be clear, though the Wechat public platform is not strong as microblog in information publicity, it achieves the point-to-point information distribution. This effectively guarantees information distribution in university libraries, so that the delivery rate of point-to-point information reaches one hundred percent ${ }^{[2]}$.

Inquiry service is self-support. Self-support inquiry service in university libraries is that readers can effectively get their information by self-help services without communicating or exchanging with librarians in university libraries. Therefore, taking advantage of the Wechat public platform can enhance backstage service management in libraries. For example, librarians in university libraries can set auto-response services, which allow readers to search information on this platform without limitations of space and time. Readers do not need to enter the library and they can rely on computers or fixed phone or places with Internet to get the latest information released by the library by just tapping several keys. Moreover, university libraries can integrate library circulation system with Wechat official accounts favorably and construct a personal center for readers, where readers can know their loan period, the time of the return for books and borrowing authority. This function is also a key project in mobile services construction in university libraries, which will provide more convenience to readers and make Wechat official accounts accepted by readers widely.

The resource pushing is individual. University libraries can use the backstage management system of public platform to collect readers' borrowing information and group readers based on their needs. To supply targeted literature experience for readers based on their ages, expertise, hobbies and other content can meet the individual needs. It is a good way to collect college teachers and students' information to establish a relevant database, so that libraries can recommend targeted literature to teachers and students based on the collected information. For example, university libraries can integrate library circulation system with Wechat official accounts favorably to supply personalized recommendation service to readers. After binding with library card, readers can click recommendation window. Then the backstage system collects readers' need information and makes an analysis on it to recommend personalized information to readers. This function can not only meet the readers' specialized needs and distribute needed literature to readers, but also make readers know the personalized reading services in university library and enhance readers' enthusiasm to library collections in university libraries. This will improve the utilization of literature in university libraries and enhance the value of the university library construction ${ }^{[3]}$. 
Interaction is private. In the traditional management system of university libraries, librarians search information after they receive readers' counseling message and then give a feedback to readers about query results. Moreover, they should reply to readers' suggestions advice and reasonable reading-relevant requirements, and meet the reasonable requirements as much as possible. The construction of Wechat official accounts in university libraries generates a new path to consultation service, which narrows the distance between readers and university libraries, so that they can have favorable communications. Compared to the open communication model of Microblog, the Wechat public platform can achieve private one-to-one communication in cyberspace, which can protect personal privacy and avoid divulging consulting information. This benefits readers and protects the interests of university libraries. This one-to-one communication model makes readers respected, enhances the humanization of library services and improves readers' love of university libraries.

The library service in the university is diverse. Ways of information exchange on Wechat are more diverse and university libraries can take advantage of this to supply diverse mobile services. When readers consult librarians through the Wechat official account, staff in university libraries can give better answers based on the consulting information. These answers can be in diverse forms, such as text, picture, audio and video animation. This will help people solve problems effectively and meet the readers' actual needs. Of course, the university library can also use Wechat public platform to supply other mobile services to readers. For example, when there is a professor's lecture in the university library and many students cannot attend it because of class time or other activities, the Wechat official account can record this lecture. Therefore, students who did not listen to this lecture can find the audio on this platform. This makes the function of the university library more comprehensive and user-friendly.

An Outlook of Mobile Library Services in the University through Wechat Public Platforms There are many advantages for university libraries to carry out mobile services through Wechat. However, many urgent problems still exist, such as how to expand mobile services in the university library, how to optimize services and how to improve ways to provide friendly and modern library services to readers. There is no doubt that the construction of the Wechat public platform has become an important way to strengthen reference and consulting services. The reference and consulting services in university libraries cannot be limited to inquiry and feedback but provide more advanced reference and consulting services based on Wechat, such as vocational counsel, thesis writing guidance and many other advisory services. The coverage of free WiFi network continues to expand, including a large area of our campus. The 4G Internet age is coming which greatly satisfies users' need of wireless services. It also can transfer videos with high image quality. The university library can take advantage of this and hold readership symposium on the Wechat official account to promote the development of the university library ${ }^{[4]}$.

\section{Conclusion}

Wechat, a new media, is accepted by many users and has become an important platform for the information release of the university library. Relevant workers need to continue to strengthen research efforts to conduct comprehensive and valuable development of mobile library services which is based on the actual situation of the construction development of the university library. They should take advantage of Wechat to promote the development of the university library.

\section{References}

[1] Chen Ying. The Wechat Public Platform and Its Application and Research on Library Mobile Services [J]. Journal of Library Science.2013 (20): 71-75

[2] Zhang Junyi, Yang Jiulong, Deng Yuan. A Research on the Status and Countermeasures of WeChat Application in Libraries in Universities of 211 Project [J]. Researches in Library Science .2014 (6): 29-34 
[3] Xu Caixia, Wei QiYu. The Application of Wechat to Library Services in Universities in Mobile Media Era [J]. New Century Library .2013 (10): 43-47

[4] Huang Haobo. The Status and Suggestions of WeChat Services in the University Libraries [J]. Researches in Library Science.2014 (3): 60-63 